\title{
Characterization of starter-free Queso Fresco made with sodium-potassium salt blends over 12 weeks of $4^{\circ} \mathrm{C}$ storage
}

\author{
D. L. Van Hekken, ${ }^{1}$ M. H. Tunick, J. A. Renye Jr., and P. M. Tomasula \\ USDA, Agricultural Research Service, Eastern Regional Research Center, Dairy and Functional Foods Research Unit, Wyndmoor, PA 19038
}

\section{ABSTRACT}

Development of reduced-sodium cheese to meet the demands of consumers concerned about sodium levels in their diet is challenging when a high-moisture, higher $\mathrm{pH}$, fresh cheese, such as Queso Fresco (QF), depends on its $\mathrm{NaCl}$ salt content to obtain its signature flavor and quality traits. This study evaluated the effects of different Na-K salt blends on the compositional, sensorial, microbial, functional, and rheological properties of QF stored for up to 12 wk at $4^{\circ} \mathrm{C}$. Queso Fresco curd from each vat was divided into 6 portions and salted with different blends of $\mathrm{NaCl}-\mathrm{KCl}(\mathrm{Na}-\mathrm{K}, \%)$ : $0.75-0.75,1.0-0.5,1.0-1.0,1.0-1.3,1.0-1.5$, and $2.0-0$ (control). Within this narrow salt range (1.5 to $2.5 \%$ total salt), the moisture, protein, fat, and lactose levels; water activity; $\mathrm{pH}$; and the textural and rheological properties were not affected by salt treatment or aging. The total salt, sodium, potassium, and ash contents reflected the different $\mathrm{Na}-\mathrm{K}$ ratios added to the QF. Total aerobic microbial count, overall proteolysis, the release of casein phosphopeptides, and the level of volatile compounds were affected by aging but not by the salt treatment. Only the 1.0-1.3 and 1.0-1.5 Na-K cheeses had sensory saltiness scores similar to that of the 2.0-0 Na-K control QF. Loss of free serum from the cheese matrix increased steadily over the $12 \mathrm{wk}$, with higher losses found in QF containing 1.5\% total salt compared with the higher Na-K blends. In conclusion, $\mathrm{KCl}$ substitution is a viable means for reduction of sodium in QF resulting in only minor differences in the quality traits, and levels of 1.0-1.3 and 1.0-1.5 Na-K are recommended to match the saltiness intensity of the 2.0-0 Na-K control. The findings from this study will aid cheese producers in creating reduced-sodium QF for health-conscious consumers.

Key words: Hispanic-style cheese, reduced sodium

Received September 30, 2016.

Accepted February 24, 2017.

${ }^{1}$ Corresponding author: Diane.VanHekken@ars.usda.gov

\section{INTRODUCTION}

Sodium chloride, $\mathrm{NaCl}$, is an essential ingredient in cheese, affecting its flavor, functionality, texture, and safety (Guinee and Fox, 2004; Johnson et al., 2009). Yet, sodium in the diet has become a health issue over the past few years because excessive amounts may have negative associations with heart and kidney diseases, among others (USDA, 2010). Although debate continues as to how much sodium should be in the diet, many health-conscious consumers are interested in reducing their sodium intake for general wellness considerations, while others are required to reduce their sodium intake because of existing health concerns such as high blood pressure.

Although low-sodium foods may be viewed as healthier alternatives, a reduction in salt may have detrimental effects on the expected quality, including flavor and texture, of traditional products. Manufacture of Hispanic-style cheese in the Unites States has grown tremendously in the last 2 decades, representing 113 million kilograms or $2.2 \%$ of all cheese made in the United States in 2015 (NASS, 2016). Demand for the cheese has come from the growing Hispanic population and increased popularity of Latin-style foods in the United States. Queso Fresco ( $\mathbf{Q F})$ is the variety most often sold in the United States, and it is characterized as a fresh, high-moisture cheese with relatively neutral $\mathrm{pH}(>6.0)$ and a $\mathrm{NaCl}$ content of 1 to $3 \%$ (Van Hekken and Farkye, 2003).

Reducing the sodium level in QF is challenging when simultaneously attempting to maintain the expected quality, including its signature salty flavor. Rapid chilling of QF after pressing and immediate vacuum packaging results in a commercial fresh cheese that maintains its quality for up to $8 \mathrm{wk}$. However, microbial and textural qualities of starter-free QF containing $<1.0 \% \mathrm{NaCl}$ were not maintained over an 8-wk storage period and were borderline acceptable at $1.0 \% \mathrm{NaCl}$ (Guo et al., 2011, 2012). At 1\% NaCl, QF contains about 30 to $50 \%$ less sodium than most commercial USmade $\mathrm{QF}$ that we have examined (unpublished data). 
Food and Drug Administration regulations state that a $25 \%$ reduction in sodium is required for a cheese to be labeled as reduced-sodium, while cheese must not exceed $140 \mathrm{mg}$ of sodium per serving size $(50 \mathrm{~g}$ for cheese; about $0.7 \% \mathrm{NaCl}$ ) to be labeled as low-sodium (FDA, 2017). Without a federal standard of identity for QF, salt content is established by the manufacturer.

Consumers use saltiness as a defining taste attribute that influences their overall acceptance of a cheese (Schroeder et al., 1988), and they can detect a $25 \%$ reduction in salt in some cheeses (Johnson et al., 2009). Reducing $\mathrm{NaCl}$ also influences microbial growth and metabolism, which alters secondary proteolysis and can lead to bitterness and poor body development (Guinee and Fox, 2004). Salt substitutes, such as $\mathrm{KCl}$, are typically added to cheese with lower sodium levels to improve salty notes, yet care must be taken to maintain the flavor profile. High concentrations of $\mathrm{KCl}$ have been reported to introduce an acid or bitter off-flavor, while other salt substitutes add a savory note that may be acceptable in some aged cheeses but would not be appropriate in a fresh cheese such as QF. Grummer et al. (2012) reported that water activity $\left(\mathbf{a}_{\mathrm{w}}\right)$ in reducedsodium cheese using mineral replacers must be matched to full $\mathrm{NaCl}$ control to minimize differences in quality.

Because $\mathrm{KCl}$ is less effective than $\mathrm{NaCl}$ in inhibiting microbial growth (Guinee and Fox, 2004), the proteolysis and $\mathrm{pH}$ during matrix development may be altered and change many of the quality properties of the cheese. Compared to $\mathrm{NaCl}$ controls, the use of $\mathrm{KCl}$ in brine resulted in higher proteolysis in Akawi (Ayyash et al., 2012) but not in feta (Katsiari et al., 2000). Grummer et al. (2012) reported that 2-mo-old Cheddar containing sea salt was harder than cheese made with just $\mathrm{NaCl}$ or a $\mathrm{NaCl}-\mathrm{KCl}$ blend and that $\mathrm{NaCl}$ plus $\mathrm{KCl}$ substitutes resulted in less cohesive and more adhesive Cheddar. Other studies have reported no differences in hardness, cohesiveness, or adhesiveness when $\mathrm{KCl}$ substitutes were used in Cheddar (Fitzgerald and Buckley, 1985) or Akawi (Ayyash et al., 2012) cheese.

With the goal to make a QF with less sodium and acceptable quality traits and shelf life, the objectives of this study were to determine the effects of reducing the $\mathrm{NaCl}$ content to 0.75 or $1.0 \%$ and adding $\mathrm{KCl}$ to obtain total salt levels of 1.5 to $2.5 \%$ on the quality characteristics of starter-free $\mathrm{QF}$ over $12 \mathrm{wk}$ of $4^{\circ} \mathrm{C}$ storage. A narrow 1.5 to $2.5 \%$ total salt range was selected to test saltiness at two 1:1 NaCl:KCl (Na-K) ratios, 0.750.75 and 1.0-1.0; reduce the $\mathrm{NaCl}$ level to $1.0 \%$ where quality traits began to change; and set at a maximum of $1.5 \%$ added $\mathrm{KCl}$, a level at which off-flavors began to be detected. A 1.0-1.3 Na-K blend was included to match the $\mathrm{a}_{\mathrm{w}}$ of the $2.0-0 \mathrm{Na}-\mathrm{K}$ control.

\section{MATERIALS AND METHODS}

\section{Cheesemaking}

Starter-free QF $(\mathrm{n}=3)$ were made as described by Guo et al. (2011) with modifications to salt treatments. Briefly, milk (200 L) that had been homogenized, pasteurized, warmed to $32^{\circ} \mathrm{C}$, and treated with $\mathrm{CaCl}_{2}$ was coagulated with chymosin $(13 \mathrm{~mL} / 100 \mathrm{~L}$ of milk; ChyMax, Chr. Hansen Inc., Milwaukee, WI); no starter culture was added. Curd was cut after 30 min, cooked at $39^{\circ} \mathrm{C}$ for $30 \mathrm{~min}$, separated from the whey by draining the whey from the vat, chilled to $15^{\circ} \mathrm{C}$, and fine milled. Curd was then divided into six 5 -kg portions and received 1 of 6 salt treatments (wt/wt): $\mathrm{NaCl}$ (Morton Salt, Chicago, IL) was maintained at $1.0 \%$ and $\mathrm{KCl}$ (Morton Salt) was added at 0.5, 1.0, 1.3, and 1.5\%; a $2 \% \mathrm{NaCl}$ control and a $0.75 \% \mathrm{NaCl}-0.75 \% \mathrm{KCl}$ QF were also made $(1.0-0.5,1.0-1.0,1.0-1.3,1.0-1.5,2.0-0$, and 0.75-0.75 Na-K, respectively). All Na-K blends met the legal definition for reduced-sodium cheese. Curds for each treatment were packed into individual molds (10 $\mathrm{cm} \times 20 \mathrm{~cm} \times 25 \mathrm{~cm}$ ) and horizontally pressed at 200 $\mathrm{kPa}$ for $12 \mathrm{~h}$ at $22^{\circ} \mathrm{C}$. The next morning, as each treatment was removed from the mold, an interior portion of the cheese was collected aseptically for division and vacuum packing of samples for microbiology assays, another portion was removed for cutting and vacuum packing for the free serum study, and the remaining cheese was divided into 4 blocks to be stored at $4^{\circ} \mathrm{C}$ for up to 12 wk. At wk 1, 4, 8, and 12, 1 block from each salt treatment was removed from storage and divided for various assays.

\section{Chemical and Physiochemical Properties}

Composition, $p H$, and Water Activity. Cheese composition, water activity, and $\mathrm{pH}$ were measured at wk 1, 4, 8 and 12 as described by Guo et al. (2011). Moisture $(\mathrm{n}=3)$ was determined using the forced-draft oven method (no. 948.12; AOAC International, 2000). Fat content $(n=2)$ was quantified based on a modified Babcock procedure (Kosikowski and Mistry, 1997). Total nitrogen levels $(\mathrm{n}=2)$ were determined using a nitrogen analyzer (Flash EA1112; Thermo Fisher Scientific, Lakewood, NJ) and multiplied by 6.38 to obtain protein content. Lactose levels $(\mathrm{n}=3)$ were determined on cheese filtrates using a lactose analyzer (Application Note 320, model YSI 2700 Select, YSI US, Yellow Springs, $\mathrm{OH})$. Ash samples $(\mathrm{n}=3)$ were generated using furnace method (Lindberg Furnace, Watertown, WI) (no. 945.46; AOAC International, 2000). Initial salt levels $(\mathrm{n}=2)$ were measured using high-range chloride titrator strips (Hach Co., Loveland, CO), and 
specific sodium and potassium levels were quantified on ash samples dissolved in $2 \%$ nitric acid $(\mathrm{n}=2)$ using an inductively coupled plasma spectrometer (iCAP 6300 Duo, Thermo Fisher Scientific, Lakewood, NJ). Salt in moisture $(\mathbf{S} / \mathbf{M})$ was calculated using [total salt (from chloride titrator strips) $/ \%$ moisture $] \times 100$. An Aqualab CX2 water activity unit (Decagon Devices Inc., Pullman, WA $)$ was used to record $\mathrm{a}_{\mathrm{w}}(\mathrm{n}=3)$ of the samples. A pH meter equipped with a point tip probe (model 611; Orion Research Corp., Cambridge, $\mathrm{MA}$ ) was used to measure $\mathrm{pH}$ within the cheese block $(\mathrm{n}=6)$.

Proteolysis. Protein profiles were created to track proteolysis of major caseins using SDS-PAGE protocols described by Van Hekken et al. (2013a). Briefly, water-soluble proteins were isolated in the supernatant of cheese samples homogenized (model 23, VirTis Co., Gardiner, NY) in a Tris-EDTA-SDS-dithiothreitol buffer and centrifuged at $39,000 \times g$ for $60 \mathrm{~min}$ at $4^{\circ} \mathrm{C}$. Lyophilized protein extracts were dissolved in a buffer containing Tris-EDTA-SDS buffer $(2 \times$ Laemmli sample buffer, BioRad, Hercules, CA) with added mercaptoethanol. Samples were separated on $20 \%$ homogeneous ultra-thin polyacrylamide gels (GE Healthcare BioSciences Corp., Piscataway, NJ) using a PhastSystem (GE Healthcare Bio-Sciences Corp.). Protein bands were stained with Bio-Safe Coomassie (BioRad). Gels were scanned (V700 Photoscanner; Epson America, Inc., Long Beach, CA) and images analyzed using ImageQuant software (version 8.1; GE Healthcare BioSciences Corp.).

Casein Phosphopeptides. Water-soluble protein samples extracted for PAGE were also used as the starting material to extract casein phosphopeptides (CPP) based on the methodology by Miquel et al. (2005) as modified by Tunick et al. (2016). Briefly, peptides were isolated in the supernatant of water-soluble protein samples that had been dissolved in Tris, $\mathrm{pH} 8$, with $\mathrm{CaCl}_{2}$ and then ethanol added, and finally centrifuged at $1,200 \times g$ for $30 \mathrm{~min}$ at $10^{\circ} \mathrm{C}$. The resulting pellet was rinsed again with ethanol and centrifuged, and the 2 supernatants were combined with a small amount of water and lyophilized. Lyophilized peptides were dissolved in $0.1 \%$ formic acid and filtered to remove peptides larger than $10 \mathrm{kDa}$ (Ultracel YM-10; EMD Millipore Corp., Darmstadt, Germany) before being injected into a reverse-phase ultra-performance liquid chromatography system (Nano-Acquity UPLC; Waters, Milford, MA) fitted with a trap column (Symmetry $\mathrm{C} 18,5 \mu \mathrm{m}, 180 \mu \mathrm{m} \times 20 \mathrm{~mm}$; Waters) and a separation column (Nano-Acquity HSS T3, $1.8 \mu \mathrm{m}, 75$ $\mu \mathrm{m} \times 150 \mathrm{~mm}$; Waters) and using a aqueous gradient of 5 to $40 \%$ acetonitrile $/ 0.1 \%$ formic acid. A quadru- pole time-of-flight analyzer mass spectrometer (Synapt G1; Waters) controlled by MassLynk Software (version 4,1 ; Waters) was used to further characterize separated peptides for identification using a milk proteins database from UniProt Knowledgebase (www.uniprot.org/ help/uniprotkb), the ProteinLynk Global Server (version 4.1, Waters), and database search parameters of phosphorylation at serine sites (Ser-P), methionine oxidation, and nondigestion enzyme. Mass spectrometric data were analyzed in triplicate, and peptide sequences appearing in all 3 runs were determined to be real.

Fatty Acid Profile. Lipid profiles were created to track the shifts in fatty acid (FA) levels at wk 1, 4, 8 , and 12 based on the procedure by Christie (2003). Briefly, liquid lipids collected from QF warmed to $40^{\circ} \mathrm{C}$, were converted to methyl esters by using hexane, sodium methoxide, glacial acetic acid, and $\mathrm{CaCl}_{2}$; after centrifugation, hexane was evaporated from the supernatant. Fatty acids were suspended in ethyl acetate and injected $(\mathrm{n}=2)$ into a gas chromatograph (HP 6980; Hewlett-Packard, Santa Clara, CA) fitted with a SP-2380 fused silica capillary column $(60 \mathrm{~m} \times 0.25$ $\mathrm{mm}$; Supelco, Bellefonte, PA) and equipped with flame ionization detector. The reference standards included C4:0-C24:0 methyl esters and conjugated methyl linoleate (GLC448 and UC-59M, respectively; Nu-Chek Prep, Elysian, MN).

Volatiles. Volatile compounds were extracted from cheese and evaluated using GC-MS as described by Tunick et al. (2012). Briefly, finely chopped cheese $(5 \mathrm{~g})$ was sealed in a vial with $10 \mu \mathrm{L}$ of $100-\mathrm{mg} / \mathrm{kg}$ 2-methyl-3-heptanone (Sigma Aldrich, St. Louis, MO) internal standard. The vial was warmed at $60^{\circ} \mathrm{C}$ for 10 min before a SPME fiber (50/30 $\mu \mathrm{m}$ DVB/Carboxen/ PDMS Stableflex, Supelco) was inserted to absorb volatile compounds for $30 \mathrm{~min}$. The fiber was then inserted into a GC-MS (7890A GC/5975 MS detector; Agilent Technologies, Wilmington, DE) fitted with a DB-5 column (30-m, 0.25-mm i.d., 0.25- $\mu \mathrm{m}$ film thickness; Agilent Technologies) to deabsorb for 5 min into a splitless injector held at $250^{\circ} \mathrm{C}$ and at a flow of 1 $\mathrm{mL}$ helium/min. NIST Standard Reference Database 1A NIST/EPA/NIH Mass Spectral Library (NIST05) in the instrument's ChemStation software was used to analyze MS results and identify volatiles.

\section{Microbiology}

Cheese samples (approximately $15 \mathrm{~g}, 1 \mathrm{~cm} \times 1 \mathrm{~cm} \times$ $8 \mathrm{~cm}$ ) were individually vacuum packed in sterile 3-mil nylon polyethylene pouches (Prime Source Vacuum Products, San Jose, CA), and stored at $4^{\circ} \mathrm{C}$. Two randomly selected bags were chosen at wk $0,2,4,6,8,10$, 
and 12 for microbiological analysis. Ten-gram samples were homogenized in $90 \mathrm{~mL}$ of sterile $2 \%$ sodium citrate with a Stomacher 400C (Seward Ltd., London, UK) at $230 \mathrm{rpm}$ for $2 \mathrm{~min}$. Serial dilutions of homogenate $(1: 10)$ were prepared in sterile sodium citrate buffer and used to inoculate agar media. Total aerobic bacteria were enumerated on plate count agar (PCA; Oxoid, Basingstoke, UK) incubated at $30^{\circ} \mathrm{C}$ for $48 \mathrm{~h}$. Psychrophilic bacteria were screened for on PCA incubated at $5^{\circ} \mathrm{C}$ for $12 \mathrm{~d}$. Following incubation, agar media were analyzed for the number of colony-forming units and colony morphology. Colony-forming unit counts were performed on 2 different dilution plates, with numbers ranging between 10 and $200 \mathrm{cfu} /$ plate; the limit of detection was $100 \mathrm{cfu} / \mathrm{g}$ of cheese.

Molecular identification of bacterial isolates from the starter-free QF was performed on a minimum of 2 colonies with the same morphology after overnight growth in brain heart infusion broth. One microliter of the overnight culture was used as template for PCR amplification of $16 \mathrm{~S}$ rDNA using eubacterial oligonucleotide primers EubA and EubB (Cottrell and Kirchman, 2000). The PCR products were cleaned with the QIAquick PCR Purification Kit (Qiagen Inc., Valencia, $\mathrm{CA}$ ), and nucleic acid sequencing was performed using an ABI Prism 3730 (Perkin-Elmer, Wellesley, MA) DNA analyzer with ABI Prism Big Dye terminator cycle sequencing reagent. Sequences were analyzed using Sequencher 54.2 (Gene Codes Corp., Ann Arbor, MI) and compared with sequences available in GenBank using the National Center for Biotechnology Information BLASTN search program (www.ncbi.nlm.nih.gov/ $\mathrm{BLAST} /$ ).

\section{Sensory}

Evaluation of saltiness for QF made with Na-K blends was conducted on samples from one vat of cheese. Evaluations were conducted on d 6 after manufacture after microbial evaluation by a licensed laboratory to ensure food safety. A discussion group, which consisted of 6 panelists, each with over $50 \mathrm{~h}$ of training and experience in flavor descriptive analysis of Hispanic-style cheese, received a refresher training session on salt intensity levels in solutions and cheese the day before evaluating samples. Samples $\left(2.5 \mathrm{~cm}^{3}\right)$ cut the day of testing were placed in 3-oz capped cups and refrigerated; samples were warmed to room temperature for $30 \mathrm{~min}$ before evaluation. Flavor profiles analysis of samples (2 per treatment) for salt intensity was conducted using a universal Spectrum 15-point intensity scale with salt intensity references at 2.5 and 5 (Meilgaard et al., 1999) and screened for the pres- ence of potassium off-flavors. A roundtable discussion was then held to reach a consensus on the detection and description of the off-flavors. Sensory analysis was conducted to confirm that Na:P blends approached the saltiness of the control $(2 \% \mathrm{NaCl}$, intensity of 2$)$ yet were not overwhelmed by potassium bitterness; consumer acceptance or preference of the saltiness of $\mathrm{QF}$ was not an objective of this study.

\section{Free Serum}

Loss of free serum (wheying off) from the cheese matrix was measured using a modification to the protocol described by Van Hekken et al. (2012). Multiple cheese blocks (approximately $20 \mathrm{~g}, 2 \mathrm{~cm} \times 3 \mathrm{~cm} \times$ $1.5 \mathrm{~cm}$ ) were cut on d 1 , weighed, individually vacuum packed, and stored at $4^{\circ} \mathrm{C} ; 3$ randomly selected bags were removed at wk $0,1,2,4,6,8,10$, and 12 . Cheese blocks were carefully removed from the bag, blotted dry, and weighed. Loss of free serum from the cheese matrix during storage was measured as percent weight loss (wt/wt).

\section{Rheology and Texture}

Rheology. Assays were conducted at wk 1, 4, and 8 as described by Van Hekken et al. (2013b). Viscoelastic rheological properties were determined by smallamplitude oscillatory shear analyses using an AR-2000 rheometer (TA Instruments, New Castle, DE). Briefly, 3 disks of cheese $(25.4 \mathrm{~mm}$ in diameter and 4 to 5 $\mathrm{mm}$ thick) were glued to parallel aluminum plates. Frequency sweeps were run from 1 to $100 \mathrm{rad} / \mathrm{s}$ at $0.8 \%$ strain. Values for elastic and viscous moduli $\left(\mathrm{G}^{\prime}\right.$ and $\mathrm{G}^{\prime \prime}$, respectively) obtained at $10 \mathrm{rad} / \mathrm{s}(1.6 \mathrm{~Hz})$ are reported.

Texture. Textural properties were determined by texture profile analysis using a TA.XT2 texture analyzer (Texture Technologies Corp., Hamilton, MA) operating at a crosshead speed of $100 \mathrm{~mm} / \mathrm{min}$. Four cheese cylinders (13-14 mm diameter and 13-14 mm high) were compressed twice by $75 \%$ to obtain values for hardness, springiness, and cohesion.

\section{Statistics}

Data were analyzed using a randomized split plot design to determine the effects of cheese (vat), aging (weeks of storage), salt treatment, and week $\times$ treatment interaction (version 9.4; SAS Institute Inc., Cary, NC). A PROC MIXED model was used to conduct ANOVA using a Bonferroni LSD test to determine significant differences $(P<0.05)$. 


\section{RESULTS AND DISCUSSION}

\section{Composition and Physiochemical Properties}

Composition, pH, and Water Activity. At wk 1, all QF contained $56.3 \pm 0.6 \%$ moisture, $20.6 \pm 0.3 \%$ protein, $20.5 \pm 0.2 \%$ fat, and $3.1 \pm 0.1 \%$ lactose; no significant differences were noted among salt treatments or between wk 1 and $12(P>0.05)$. As expected, characteristics based on salt content, such as the total salt, sodium, potassium, and ash concentrations and $\mathrm{S} / \mathrm{M}$ values, reflected the different added amounts of $\mathrm{NaCl}$ and $\mathrm{KCl}$ (Table 1). Although the $\mathrm{a}_{\mathrm{w}}$ did not differ $(P>0.05)$ among individual salt treatments, overall differences in $\mathrm{a}_{\mathrm{w}}$ were observed at wk 1, 0.963 to 0.969 , and wk $12,0.974$ to $0.979(P<0.05)$. The $\mathrm{pH}$ of the samples remained very stable, $\mathrm{pH} 6.30 \pm 0.01$ throughout the study. This stability is expected for a cheese made from pasteurized milk and without added LAB starter cultures. Although bacteria not destroyed during pasteurization will persist in QF (see Microbiology section for more details), $\mathrm{pH}>6.0$ indicated no excessive growth that would have affected cheese quality and shelf life.

Composition of QF fell within the wide range reported for QF (Van Hekken and Farkye, 2003). Lack of significant shifts in major components because of changing salt levels reflected the small salt range used (1.5-2.5\% total salt) and typical vat-to-vat variations. The effect of $\mathrm{NaCl}$ reduction on cheese composition can vary depending on the type of cheese and the level and method of $\mathrm{NaCl}$ reduction and $\mathrm{NaCl}$ substitution. Several studies have reported no significant composi- tional changes when using the 1:1 Na:K substitutions for Cheddar (Fitzgerald and Buckley, 1985) and feta (Katsiari et al., 2000), while other studies have reported shifts in composition when working with highly salted $(4-6 \% \mathrm{NaCl})$ or brined cheeses (Johnson et al., 2009).

Legal definitions for low- and reduced-sodium cheese are clearly stated (FDA, 2017); however, without a standard of identity for $\mathrm{QF}$, the normal $\mathrm{NaCl}$ content is determined by the manufacturer, which can range from 1 to $3 \% \mathrm{NaCl}$ (Van Hekken and Farkye, 2003). Our fullsalt control was set at $2.0 \% \mathrm{NaCl}$ to obtain the salty flavor expected in QF. All of our blended Na-K QF conformed to the minimum $25 \% \mathrm{NaCl}$ reduction to be considered reduced-sodium cheese. The lowest blend, 0.75-0.75 Na-K, approached but did not meet the required $2.8 \mathrm{mg}$ of $\mathrm{Na} / \mathrm{g}$ of cheese (about $0.7 \% \mathrm{NaCl}$ ) to be labeled as a low-sodium cheese.

Proteolysis. The SDS-PAGE protein profiles (Figure 1) showed shifts in protein and peptide bands that indicated proteolysis had occurred during aging, but comparison of the amount of protein and peptides among treatments at the same age showed that proteolysis was not affected $(P<0.05)$ by the salt treatment (Figure 2). Intact major caseins $\left(\alpha_{\mathrm{S}^{-}} \mathrm{CN}, \alpha_{\mathrm{S}^{2}} \mathrm{CN}\right.$, and $\beta$-CN), which accounted for $50 \pm 0.4 \%$ of the protein/ peptides in cheese at wk 1 , had decreased $7.1 \pm 0.4 \%$ at wk 12. As caseins underwent proteolysis, a shift in peptide bands appeared, increased in density, or did both. One of the earliest $\alpha_{\mathrm{S}_{1}} \mathrm{CN}$ peptides to be released in aging cheese, $\alpha_{S_{1}}-\mathrm{CN}$ [fragment (f) 25-199], which migrated between the intact $\alpha_{\mathrm{S}_{1}} \mathrm{CN}$ and $\beta-\mathrm{CN}$ and is labeled $24 \mathrm{kDa}$, appeared in wk 4 and accounted for $7.0 \pm 0.7 \%$ of the proteins/peptides in $\mathrm{QF}$ at wk 12 .

Table 1. Effect of salt on selected characteristics of Queso Fresco made with different Na-K salt blends ${ }^{1}$ at wk 1 and 12

\begin{tabular}{|c|c|c|c|c|c|c|c|}
\hline $\begin{array}{l}\text { Na-K treatments } \\
(\%)\end{array}$ & $\begin{array}{c}\text { Total salt }{ }^{2} \\
(\%)\end{array}$ & $\begin{array}{c}\mathrm{Na} \\
(\mathrm{mg} / 100 \mathrm{~g} \text { of curd })\end{array}$ & $\begin{array}{c}\mathrm{K} \\
(\mathrm{mg} / 100 \mathrm{~g} \text { of curd })\end{array}$ & $\begin{array}{l}\text { Moisture } \\
(\%)\end{array}$ & $\begin{array}{l}\text { Ash } \\
(\%)\end{array}$ & $\mathrm{S} / \mathrm{M}^{3}$ & $\mathrm{a}_{\mathrm{w}}{ }^{4}$ \\
\hline \multicolumn{8}{|l|}{ Week 1} \\
\hline $0.75-0.75$ & $1.60^{\mathrm{cd}}$ & $109^{\mathrm{c}}$ & $111^{\mathrm{bc}}$ & 57.10 & $3.48^{\mathrm{d}}$ & 2.8 & 0.968 \\
\hline $1.0-1.0$ & $1.97^{\mathrm{abc}}$ & $151^{\mathrm{b}}$ & $100^{\mathrm{cd}}$ & 56.46 & $4.00^{\mathrm{abc}}$ & 3.5 & 0.967 \\
\hline $1.0-1.3$ & $2.14^{\mathrm{ab}}$ & $129^{\mathrm{bc}}$ & $141^{\mathrm{a}}$ & 56.29 & $4.09^{\mathrm{ab}}$ & 3.8 & 0.965 \\
\hline $1.0-1.5$ & $2.41^{\mathrm{a}}$ & $125^{\mathrm{bc}}$ & $142^{\mathrm{a}}$ & 55.43 & $4.41^{\mathrm{a}}$ & 4.3 & 0.963 \\
\hline \multicolumn{8}{|l|}{ Week 12} \\
\hline $0.75-0.75$ & $1.52^{\mathrm{cd}}$ & $111^{\mathrm{c}}$ & $98^{\mathrm{cd}}$ & 55.87 & $3.64^{\mathrm{cd}}$ & 2.7 & 0.978 \\
\hline $1.0-0.5$ & $1.50^{\mathrm{d}}$ & $140^{\mathrm{b}}$ & $77^{\mathrm{d}}$ & 56.09 & $3.42^{\mathrm{d}}$ & 2.7 & 0.979 \\
\hline $1.0-1.0$ & $1.76^{\mathrm{bcd}}$ & $140^{\mathrm{b}}$ & $99^{\mathrm{cd}}$ & 54.82 & $3.89^{\mathrm{abc}}$ & 3.2 & 0.978 \\
\hline $1.0-1.3$ & $1.92^{\mathrm{bc}}$ & $131^{\mathrm{bc}}$ & $136^{\mathrm{a}}$ & 55.10 & $4.17^{\mathrm{ab}}$ & 3.5 & 0.976 \\
\hline $1.0-1.5$ & $2.07^{\mathrm{ab}}$ & $125^{\mathrm{bc}}$ & $139^{\mathrm{a}}$ & 54.85 & $4.33^{\mathrm{ab}}$ & 3.8 & 0.977 \\
\hline $2.0-0$ & $1.94^{\mathrm{abc}}$ & $209^{\mathrm{a}}$ & $26^{\mathrm{e}}$ & 55.55 & $3.66^{\mathrm{cd}}$ & 3.5 & 0.974 \\
\hline
\end{tabular}

${ }^{\mathrm{a}-\mathrm{e}}$ Means with the same superscript within a column are not significantly different $(P<0.05)$.

${ }^{1}$ Salt blends (\%, NaCl-KCl): 2.0-0, 0.75-0.75, 1.0-0.5, 1.0-1.0, 1.0-1.3, and 1.0-1.5.

${ }^{2}$ Total salt $=\% \mathrm{NaCl}+\% \mathrm{KCl}$.

${ }^{3} \mathrm{~S} / \mathrm{M}=$ salt in moisture.

${ }^{4} \mathrm{a}_{\mathrm{w}}=$ water activity. 


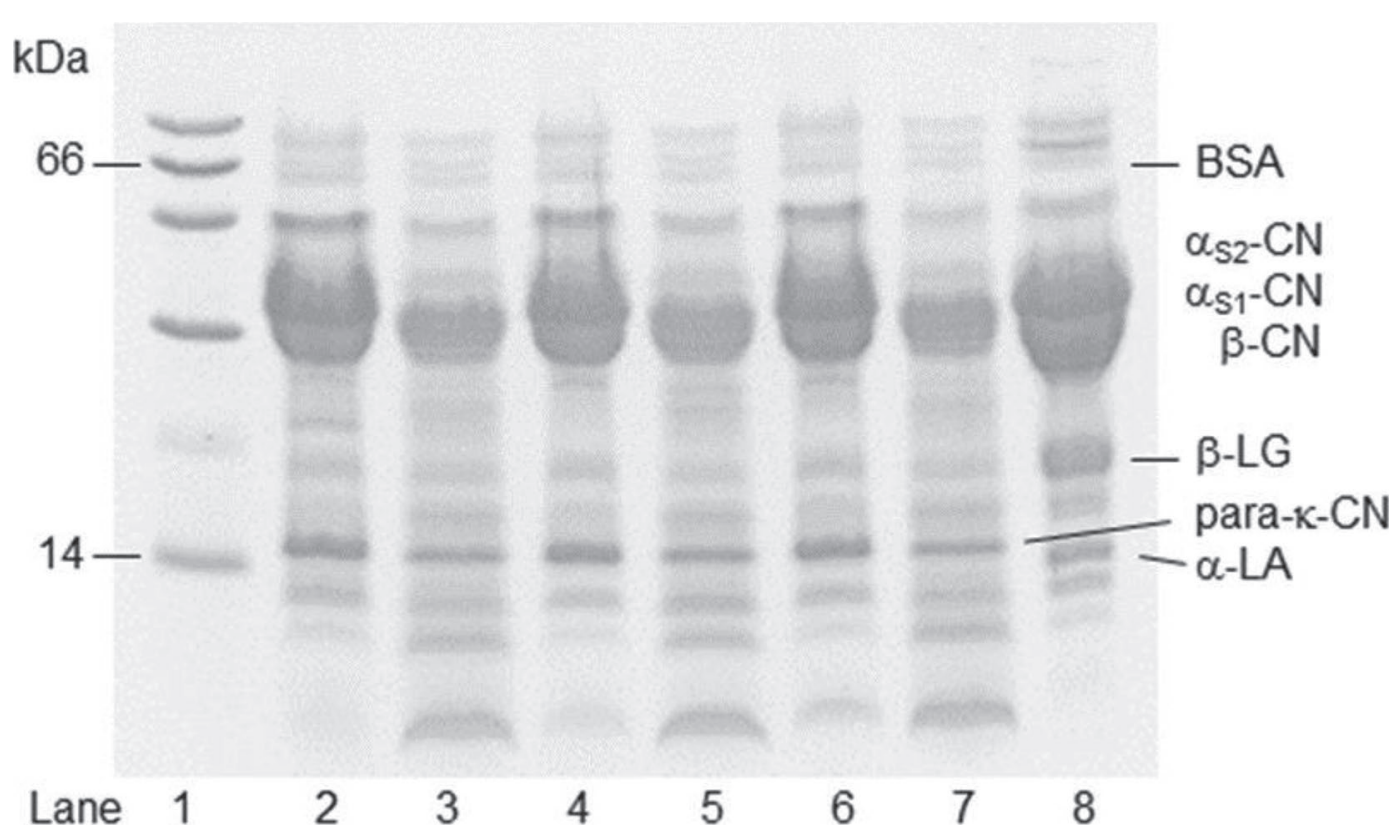

Figure 1. Protein profiles for Queso Fresco made with different Na-K blends at wk 1 (lanes 2, 4, and 6) and wk 12 (lanes 3, 5, and 7), low molecular weight standard (lane 1), and bovine milk standard (lane 8). Salt blends (\%, NaCl-KCl): 2.0-0 (lanes 2 and 3), 0.75-0.75 (lanes 4 and 5), and 1.0-1.5 (lanes 6 and 7 ).

Migrating ahead of $\beta$-CN was a series of peptide bands derived from the caseins, which were divided into 3 ranges using major whey proteins as division points; ranges included 18.5 to $23 \mathrm{kDa}$ (between $\beta$-LG and $\beta-\mathrm{CN}$ ), 14.5 to 18 ( $\alpha-\mathrm{LA}$ to $\beta-\mathrm{LG}$ ), and 10 to $14 \mathrm{kDa}$ (leading edge to $\alpha$-LA). Peptides $<10 \mathrm{kDa}$ were allowed to migrate off the gel to improve the resolution of the native caseins. An increase $(4.2 \pm 0.8 \%)$ in the small peptides appeared in the 10 to $14 \mathrm{kDa}$ range. Although a shift in bands occurred within the remaining ranges over time, the relative quantity within the ranges had not changed $(P>0.05)$. Queso Fresco contained 55\% moisture, therefore, about 5 to $7 \%$ of the minor whey proteins $(>66 \mathrm{kDa})$ remained in the cheese and decreased slightly to 3 to $5 \%$ by wk 12 .

Without addition of starter cultures and their associated enzymes, proteolysis that occurred in the $\mathrm{QF}$ was driven by the coagulant enzyme, other indigenous milk enzymes that were not inactivated by pasteurization, and enzymes from bacteria that either survived pasteurization or were postcontaminants to the open cheese vat. The $\alpha_{\mathrm{S}^{-}}$and $\beta$-CN are more readily hydrolyzed by chymosin than $\alpha_{S_{2}}-\mathrm{CN}$ and, once native $\kappa-\mathrm{CN}$ is cleaved by chymosin in the coagulation step, $\kappa-\mathrm{CN}$ (f 1-105) remaining in the curd is fairly resistant to hydrolysis (Upadhyay et al., 2004). Although overshadowed by chymosin, the milk enzyme plasmin will hydrolyze $\beta$ - and $\alpha_{\mathrm{S}^{-}} \mathrm{CN}$, and to a lesser degree, $\alpha_{\mathrm{S}_{1}} \mathrm{CN}$, but not k-CN (Bastian and Brown, 1996). Although the $\mathrm{pH} 6.3$ of QF may not have been optimal for chymosin activity (Upadhyay et al., 2004), the spoilage bacteria that survived pasteurization persisted (see Microbiology section) and contributed proteolytic enzymes. Although results are dependent on the specific cheese, proteolytic activity of starter cultures are typically reduced at $>1.5 \% \mathrm{NaCl}$ and $>5.0 \mathrm{~S} / \mathrm{M}$ (Guinee and Fox, 2004). Reducing $\mathrm{NaCl}$, thereby increasing bacterial activity in the cheese, results in unacceptable flavor (bitter peptides) and poor quality in Cheddar-type cheese (Schroeder et al., 1988). Reduction of $\mathrm{NaCl}$ using a 1:1 $\mathrm{Na}-\mathrm{K}$ blend did not alter the degree of proteolysis in 16-wk Cheddar (Fitzgerald and Buckley, 1985) and feta (Katsiari et al., 2000) cheese.

Casein Phosphopeptides. An additional health benefit of proteolysis within the cheese matrix is the release of small phosphorylated peptides from caseins that are believed to form complexes with calcium in the human digestive tract and help in passive adsorption of minerals through the intestinal wall (Miquel et al., 2005). The key to the mineral binding function of CPP is the phosphorylated serine (Ser-P) found in bovine caseins. Several peptides were extracted from $\mathrm{QF}$ that were $\leq 3 \mathrm{kDa}$ (27 AA or less) and contained the Ser-P (Table 2). Peptides are identified by their AA sequences (Farrell et al., 2004). Bovine $\beta-C N$ contains 5 Ser-P, located in the hydrophobic N-terminal end, and it released $74 \%$ of all of the CPP identified in this study. The highest number of peptides were 

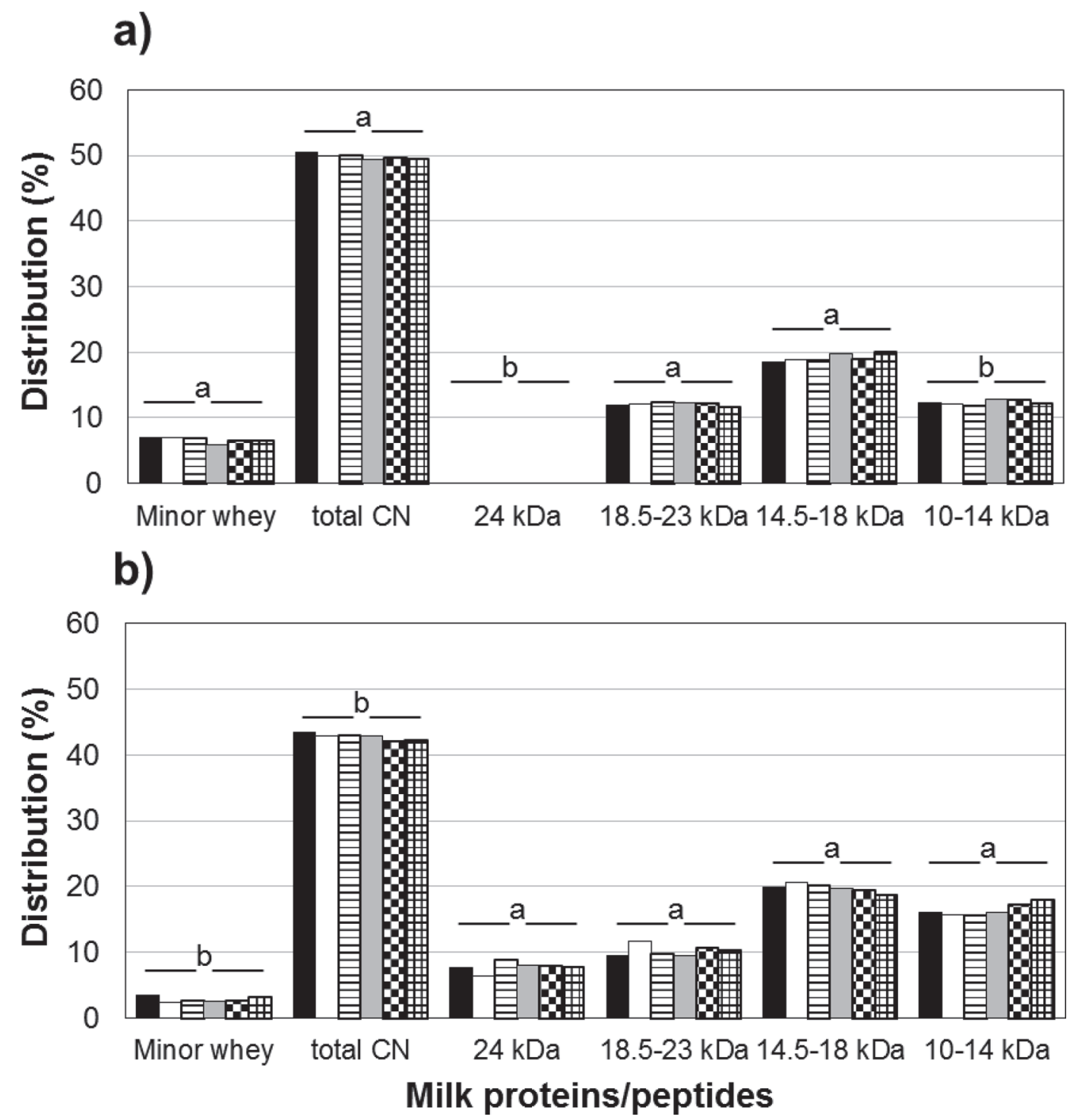

Figure 2. Distribution of casein and peptide bands in Queso Fresco made with different Na-K salt blends and aged at $4^{\circ} \mathrm{C}$ at (a) wk 1 and (b) wk 12. Although treatment means within a protein or peptide group were not different at the same age $(P>0.05)$, some significant differences $(P<0.05)$ were observed between (a) wk 1 and (b) wk 12 as shown by different lowercase letters above the bars. Salt blends $(\%, \mathrm{NaCl}-\mathrm{KCl})$ : 2.0-0, black; 0.75-0.75, white; 1.0-0.5, horizontal lines; 1.0-1.0, gray; 1.0-1.3, checked; and 1.0-1.5, grid lines.

found at wk 1 and 8 and the lowest at wk 12; the 1.0-1.5 Na-K blend consistently gave the lowest number of CPP. The $\beta$-CN CPP were categorized into 2 groups. Predominant peptides $(85 \%)$ contained Ser-P at position 35 with $\beta$-Casein (f 33-37) was common to all and was cleaved at different points within the (f 26-56) sequence. Remaining peptides (15\%) contained Ser-P at positions $15,17,18$, or 19 with $\beta$-CN (f $10-15$ ) common to all and were cleaved from the sequence (f $1-35) ; 30 \%$ of the sequences contained Ser-P triplet at (f 17-19); the numbers were highest at wk 1 and lowest at wk 12 . Bovine $\alpha_{\mathrm{S} 1}-\mathrm{CN}$ contained 9 Ser-P and released $21 \%$ of the CPP. About $96 \%$ of CPP included
Ser-P at position 115 with $\alpha_{\mathrm{S}_{1}} \mathrm{CN}$ (f 113-119) common to all and were cleaved from sequence (f 104-122). Only 2 other sequences were found in QF; Ser-P at positions 41 and $46\left[\alpha_{S 1}-\mathrm{CN}\right.$ (f $36-47$ )] and at position $75\left[\left(\alpha_{\mathrm{S}^{-}} \mathrm{CN}\right.\right.$ (f $\left.\left.69-81\right)\right]$. Peptides began to appear in $\mathrm{wk}$ 4 samples and increased with time. Although bovine $\alpha_{S_{2}-}$ CN contains 11 Ser-P, it is noted for being resistant to proteolysis during cheese ripening (Upadhyay et al., 2004), and only $5 \%$ of the identified CPP were derived from this protein. All CPP came from the (f 137-152) sequence with $\alpha_{\mathrm{S}^{2}} \mathrm{CN}$ (f 140-149) in common; CPP did not appear until wk 12 and only in 2.0-0, 1.0-1.3, and 1.0-1.5 Na-K QF. No CPP were identified as com- 
Table 2. Summary of the casein phosphopeptides (CPP) found in the Queso Fresco made with different Na-K salt blends at wk $1,4,8$, and 12

\begin{tabular}{l} 
r \\
\cline { 2 - 5 }
\end{tabular}

ing from $\kappa-\mathrm{CN}$. The only Ser-P in bovine $\kappa-\mathrm{CN}$ is at position 149 and is found in $\kappa-\mathrm{CN}$ (f 106-169) peptide, which remains in the whey; the bulk of it would have been lost when whey was drained from the vat.

Although CPP can bind with barium, cobalt, chromium, iron, magnesium, nickel, selenium, and zinc, and complexes of CPP-Na-Zn can inhibit formation of hydroxyapatite crystals (FitzGerald, 1998), the bulk of research has focused on the high affinity of CPP for calcium; the interaction between CPP and potassium has not been reported. Complexes that CPP form with calcium remain soluble within $\mathrm{pH}$ conditions of the intestine (Miquel et al., 2005) and facilitates passive adsorption of minerals in the human intestinal tract (Erba et al., 2001). Studies have reported mineral binding capabilities for the following CPP: $\alpha_{S_{1}} \mathrm{CN}$ (f 46-58), $\alpha_{\mathrm{S}_{1}} \mathrm{CN}$ (f 59-79), $\alpha_{\mathrm{S}_{2}-\mathrm{CN}}$ (f 1-32), $\alpha_{\mathrm{S}^{2}}-\mathrm{CN}$ (f $55-64$ ), $\beta-\mathrm{CN}$ (f $1-25$ ), and $\beta-\mathrm{CN}$ (f 33-48) (Meisel and FitzGerald, 2003). Only a few Ser-P peptides identified in our study had the triple Ser-P double Glu sequence noted to have the highest affinity for binding minerals (Meisel and FitzGerald, 2003; Miquel et al., 2005). Further research is needed to determine mineral binding capacities for the Ser-P peptides isolated in this study and to evaluate their potential to enhance the bioavailability of different minerals.
Fatty Acid Profile. Lipids make up 20\% of QF and are essential to many quality traits, from matrix formation and stability to formation of flavor and aroma compounds to nutritional- and health-value contributions. As expected for cheese made from pasteurized milk without added starter cultures and their contributing lipases, the distribution of the FA in the full fat QF cheese was stable $(P<0.05)$ among salt treatments and between wk 1 and 12 . The means and standard deviations ( $\mathrm{mg}$ of FA/g of lipid) for common FA were $6: 0,2.29 \pm 0.11 ; 8: 0,0.87 \pm 0.11 ; 10: 0,2.85 \pm 0.17$; $12: 0,3.38 \pm 0.15 ; 14: 0,10.5 \pm 0.5,14: 10.89 \pm 0.05 ;$ $15: 0,1.00 \pm 0.08 ; 16: 027.93 \pm 0.84 ; 16: 1,1.44 \pm 0.08$ $17: 1,0.53 \pm 0.11 ; 18: 0,11.48 \pm 0.48 ; 18: 1,26.88 \pm 0.79$ $18: 1$ trans, $4.41 \pm 0.24 ; 18: 2,3.00 \pm 0.26$; and CLA, $1.22 \pm 0.08$. Salt treatments used in this study did not affect the concentrations of C18 lipids, 18:0, 18:1, 18:1 trans, or 18:2, thought to affect human health. Fatty acid values are similar to those published in the USDA Nutrient Database for fresh QF containing 1.9\% NaCl in milligrams of FA per gram of fat bases (USDA, 2016).

In this study, the lower $\mathrm{NaCl}$ treatments $(0.75$ and $1.0 \%$ ) did not show excessive lipolysis indicative of excessive growth of spoilage bacteria that survived pasteurization (see Microbiology section for details). Guo et al. (2011) reported loss of QF quality at levels $\leq$ 
$1.0 \% \mathrm{NaCl}$ but did not examine the FA profile to track lipolysis. Torres and Chandan (1981) reported low lipolysis in QF but did not state salt content. Salt levels in semihard and hard cheeses made with pasteurized milk and added cultures are typically used to regulate microbial growth and release of lipases to carefully control lipolysis and ensure development of desired quality traits during aging.

Volatiles. Ten aromatic volatile compounds common in cheese and at levels high enough to be detected were tracked from wk 1 to 12 (Table 3). Although they appeared in all cheese samples throughout the study, considerable variation existed among salt treatments, making it difficult to determine trends outside of saying that 2.0-0 Na-K control usually had the highest levels and 1.0-1.0 Na-K blend had the lowest levels. Only pentanal decreased slightly over time (2 to $1 \mathrm{mg} / \mathrm{kg}$ ). The other 9 compounds increased in concentration as cheese aged. The most prevalent volatile compounds at $12 \mathrm{wk}$ of aging were 2-nonanone and 2-heptanone at 62 and $42 \mathrm{mg} / \mathrm{kg}$, respectively, with dramatic increases noted between wk 8 and 12. Octanoic acid and n-decanoic acid tripled to $14 \mathrm{mg} / \mathrm{kg}$ by wk 12 , whereas heptanal and nonanal peaked around $8 \mathrm{mg} / \mathrm{kg}$ at wk 12 . Hexanal and 2-pentanone increased to peak at 3 to $4 \mathrm{mg} / \mathrm{kg}$ by wk 12 , while octanal doubled to $1 \mathrm{mg} / \mathrm{kg}$ at wk 12 . Six other compounds (1-pentanal, 2-ethyl-1-hexanol, decanal, 2-undecanone, hexanoic acid, and 2H-pyran2-one) were detected by SPME, but their appearance was random, not always appearing in all samples, and they are not included in Table 3.

As expected, volatile compounds that contribute to the signature flavor of $\mathrm{QF}$ were not affected by salt blends used in this study. At 12 wk of aging, the number of volatile compounds identified in QF were fewer than the 40-plus compounds reported in fresh cheese made with starter cultures (Garde et al., 2007) and the 100plus compounds reported in aged cheeses (Frank et al., 2004). Short-chain aldehydes typically appear and then disappear early during aging of cheese as compounds convert to alcohols and acids, although aldehydes such as nonanal, which are generated by the lipolysis of longer-chain FA, would remain longer (Curioni and Bosset, 2002). Straight-chain aldehydes can enhance cheese flavor at low concentrations with green and fruity notes, yet they become unpleasant when found at levels above their thresholds (Curioni and Bosset, 2002). Ketones are common in cheese, typically increase during ripening, and bring fruity-floral notes to the cheese as well as green, blue cheese (2-heptanone), and hot milk and musty (2-nonanone) aromas. Short- and mid-chain FA are major contributors to cheese flavor, with octanoic and decanoic acids typically associated with goaty or rancid notes that become unpleasant at higher concentrations. Although 10 different volatile compounds were identified in QF, none of the sensory panelists identified any off-flavors in cheese samples, except for $\mathrm{K}$-associated acid off-flavor in the 1.0-1.5 Na-K QF.

\section{Microbiology}

Total aerobic counts for all QF samples did not differ significantly during $12 \mathrm{wk}$ of $4^{\circ} \mathrm{C}$ storage. Counts were observed to decrease by 0.6 to $1.5 \mathrm{log} \mathrm{cfu} / \mathrm{g}$ at wk 2 for QF made with $\geq 2 \%$ total salt (Figure 3 ), with total aerobic counts for these cheeses ranging between 3.6 $\pm 0.8(2.0-0 \mathrm{Na}-\mathrm{K})$ and $3.9 \pm 0.8(1.0-1.3 \mathrm{Na}-\mathrm{K}) \log$ $\mathrm{cfu} / \mathrm{g}$; while counts for cheeses containing $1.5 \%$ total salt were $5.6 \pm 0.7(0.75-0.75 \mathrm{Na}-\mathrm{K})$ and $5.5 \pm 0.7(1.0-$ $0.5 \mathrm{Na}-\mathrm{K}) \mathrm{cfu} / \mathrm{g}$ at wk 2 . Bacterial counts increased between wk 2 and 10 by 1 to $3 \log \mathrm{cfu} / \mathrm{g}$, with final bacterial load differing by $\leq 0.6 \log \mathrm{cfu} / \mathrm{g}$ for all cheeses at wk 12. Total aerobic counts at wk 12 ranged between $5.8 \pm 0.6(2.0-0 \mathrm{Na}-\mathrm{K})$ and $6.5 \pm 1.1(0.75-0.75$ $\mathrm{Na}-\mathrm{K})$. Increased bacterial counts at 12 wk of storage was not unexpected because the cheeses in this study maintained S/M and $\mathrm{a}_{\mathrm{w}}$ values (Table 1) capable of supporting bacterial growth in cheese.

Because the QF was starter-free, molecular identification of bacterial species present between wk 8 and

Table 3. Overview of the volatile compounds detected in Queso Fresco over 12 wk of storage at $4^{\circ} \mathrm{C}$

\begin{tabular}{|c|c|c|c|c|c|}
\hline Compound & Lowest (mg/kg) & At wk & Highest (mg/kg) & At wk & Associated with odor or aroma ${ }^{1}$ \\
\hline 2-Pentanone & 0.1 & 1 & 4.0 & 12 & Fruity, orange \\
\hline 2-Nonanone & 0.1 & 1 & 62 & 12 & Fruity, hot milk, musty \\
\hline 2-Heptanone & 0.1 & 1 & 42 & 12 & Green, fruity, blue cheese \\
\hline Heptanal & 0.5 & 1 & 8.0 & 12 & Soapy, rancid \\
\hline Octanal & 0.5 & 1 & 1.0 & 12 & Green, fatty \\
\hline Pentanal & 1.0 & 12 & 2.0 & 1 & Chemical, green \\
\hline Hexanal & 2.0 & 1 & 4.0 & 8 & Green, fruity \\
\hline Nonanal & 3.0 & 1 & 8.0 & 12 & Green, tallow, soapy \\
\hline Octanoic acid & 4.0 & 1 & 14 & 12 & Goat, musty, rancid \\
\hline n-Decanoic acid & 5.0 & 1 & 14 & 12 & Goat, rancid \\
\hline
\end{tabular}

${ }^{1}$ Curioni and Bosset, 2002; Le Quéré and Molimard, 2002. 
12 was carried out by $16 \mathrm{~S}$ rDNA sequencing, which identified Paenibacillus sp., Pseudomonas putida, Microbacterium sp., and Bacillus simplex in all cheese samples. These results suggest that variations in salt composition did not select for the growth of a specific contaminant. These bacterial species have all been reported as psychrotrophic contaminants capable of milk and dairy product spoilage (Hantsis-Zacharov and Halpern, 2007; Ranieri et al., 2012). Previously Guo et al. (2012) reported that $\mathrm{QF}$ made with $\leq 0.5 \% \mathrm{NaCl}$ had significantly higher total aerobic counts compared with QF made with 1.0, 1.5, or $2.0 \% \mathrm{NaCl}$ after 8 wk of storage. Similar counts observed for all cheeses in this study after 12 wk of storage suggested that replacement of $\mathrm{NaCl}$ with $\mathrm{KCl}$ did not result in a more favorable environment for bacterial growth. Suboptimal growth temperature and lack of oxygen due to vacuum packaging are expected to have negatively affected the growth of the aerobic psychrotrophs identified, thus contributing to the acceptable cheese quality maintained throughout the study. In addition, psychrophilic bacteria, which have a lower optimal growth temperature than psychrotrophs, were not observed on PCA incubated at $5{ }^{\circ} \mathrm{C}$. If present, they might have caused a more rapid degradation in cheese quality.

Another major concern with altering the type and concentration of salt used during the production of $\mathrm{QF}$ is the effect on food safety. High salt concentration used during QF manufacture is expected to prevent the growth of food-borne pathogens that would thrive in high moisture and neutral $\mathrm{pH}$ environment of $\mathrm{QF}$, including Listeria monocytogenes. Listeria monocytogenes

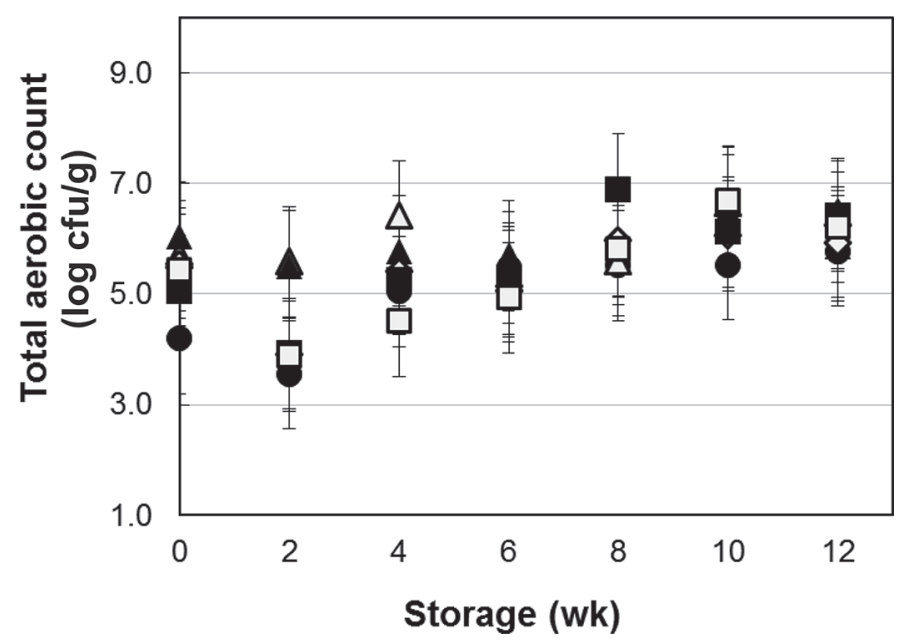

Figure 3. Distribution of total aerobic bacterial counts from Queso Fresco made with different Na-K salt blends over 12 wk of $4^{\circ} \mathrm{C}$ storage; standard error bars are included. Salt blends (\%, NaCl-KCl): 2.0-0, 1, ๑; $0.75-0.75, \Delta ; 1.0-0.5, \mathbf{\Delta} ; 1.0-1.0, \diamond ; 1.0-1.3, \mathbf{\square}$; and 1.0-1.5, $\square$. outbreaks have been associated with consumption of contaminated QF. A previous study reported that inoculated Listeria population increased by more than $4 \log$ $\mathrm{cfu} / \mathrm{g}$ in QF made with $\sim 1.7 \% \mathrm{NaCl}$ after $20 \mathrm{~d}$ of storage at either 4 or $10^{\circ} \mathrm{C}$ (Leggett et al., 2012). Another study reported that $\mathrm{KCl}$ could be used to replace $\mathrm{NaCl}$ without affecting the microbiological safety of food products (Boziaris et al., 2007). Taken together, these studies suggest that changes in salt composition tested in this study would not affect the growth or survival of Listeria. Because the main goal of this study was to demonstrate that the use of $\mathrm{KCl}$ would not affect QF quality, the cheese was not artificially contaminated with Listeria. Additional studies could be performed to test the survival of Listeria in Na-K blends of QF, but additional antilisterial treatments will most likely be required to suppress its growth.

\section{Sensory}

Based on earlier studies, a score of 2 for saltiness (based on the Spectrum intensity score of 2.5 for $0.2 \%$ $\mathrm{NaCl}$ in water; Meilgaard et al., 1999) was selected as the target saltiness for QF, which corresponded to the control cheese, 2.0-0 Na-K. Potassium chloride was selected to partially replace $\mathrm{NaCl}$ because of their chemical similarities, including the ability to provide a "salty" flavor note. Total replacement of $\mathrm{NaCl}$ with $\mathrm{KCl}$ is not recommended because it results in soft, bitter cheese with an unpleasant acid or bitter flavor (Fitzgerald and Buckley, 1985). Only one panelist detected a slight bitter potassium-associated off-flavor in the 1.0-1.5 Na-K QF. Of the Na-K blends tested, only QF containing 1.0-1.3 and 1.0-1.5 Na-K had saltiness intensities comparable to the control QF. Addition of $1.5 \% \mathrm{KCl}$ should be the highest to be considered because potassium offflavors would overwhelm the QF fresh milky flavor. Although a ratio of $1: 1 \mathrm{Na}: \mathrm{K}$ has been suggested when using Na-K blends in cheese (Fitzgerald and Buckley, 1985; Lindsay et al., 1982), levels of 0.75-0.75 and 1.0$1.0 \% \mathrm{Na}-\mathrm{K}$ in $\mathrm{QF}$ were inadequate to mimic the saltiness of $2.0 \% \mathrm{NaCl}$. A study in the early 2000s reported that consumers on the west coast of the United States preferred QF that contained 1.4 to $2.4 \%$ salt, with consumers familiar with Latin-style cheeses preferring higher ranges; the optimum was suggested at $1.8 \%$ salt and $\mathrm{pH} 6.0$ (Clark et al., 2001). Sensory evaluations definitely demonstrate that $\mathrm{Na}-\mathrm{K}$ blends of 1.0-1.3 and 1.0-1.5 had the saltiness expected in QF without being overwhelmed by potassium bitterness, yet they should only be considered as guidance for future work because our sensory evaluation was based on limited testing. Further descriptive analysis of saltiness and off-flavors in fresh and aging QF should be conducted for full 


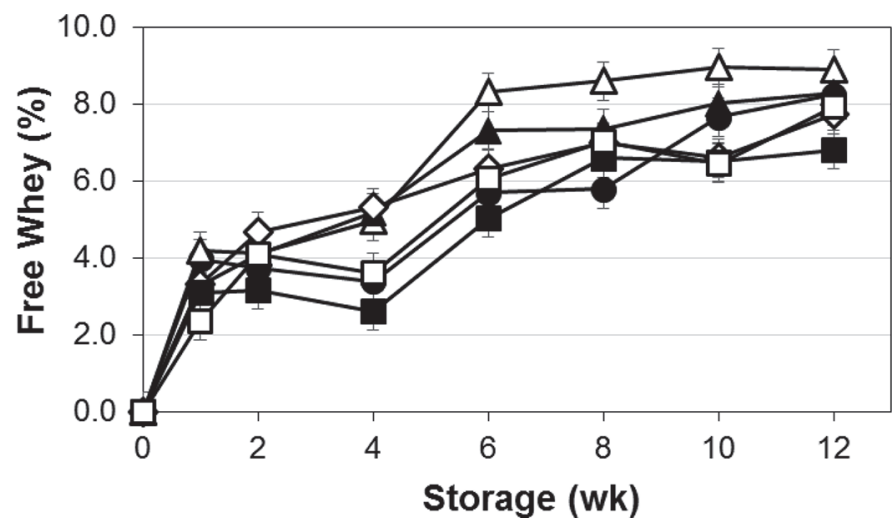

Figure 4. Distribution of accumulated free whey in packaging of Queso Fresco made with different Na-K salt blends over 12 wk of $4^{\circ} \mathrm{C}$ storage; standard error bars are included. Salt blends ( $\%, \mathrm{NaCl}-\mathrm{KCl})$ : $2.0-0, \mathbf{\bullet} ; 0.75-0.75, \Delta ; 1.0-0.5, \mathbf{\Delta} ; 1.0-1.0, \diamond ; 1.0-1.3, \mathbf{\square}$; and $1.0-1.5, \square$.

flavor profiles as well as tests of consumer difference, preference, and acceptance of reduced-sodium QF.

\section{Free Serum}

The amount of free serum (wheying off) lost from the cheese matrix and accumulated in the vacuum bag increased $(P<0.05)$ over time for all salt treatments (Figure 4). Queso Fresco containing 0.75-0.75 and 1.0-0.5 Na-K consistently had the highest loss of whey (8.2\% at wk 12) of all salt treatments, whereas QF with 1.0-1.3 Na-K had the lowest loss of whey (6.8\% at wk 12). Although 2.0-0 and 1.0-1.3 Na-K were matched for $\mathrm{a}_{\mathrm{w}}, 1.0-1.3 \mathrm{Na}-\mathrm{K}$ QF was better at retaining whey within the cheese matrix than the 2.0-0 Na-K control. The amount of whey lost in this assay does not reflect what happens in larger cheese blocks. Smaller pieces used to determine wheying off and the fragile nature of the QF matrix elevated the percent loss over $12 \mathrm{wk}$ of the study. Larger blocks of QF did have some whey accumulating in the bag during storage but only a few milliliters, which resulted in slight $(P>0.05)$ decreases in moisture content of 0.5 to $1.2 \%$ (Table 1 ).

Sodium chloride is an important factor in inducing syneresis in the curd and texture development (McMahon, 2010). Earlier studies have shown that wheying off is a problem for QF (Van Hekken et al., 2012, 2013b). Not only does QF contain $56 \%$ moisture, but also the body of the cheese is very fragile, having a short curd that crumbles very easily. Casein micelles do not fuse together as in semihard and hard cheeses, leaving a significant amount of open space within the matrix to hold moisture. Although the control and the 2 highest Na-K blends had the least amount of wheying off during the first $4 \mathrm{wk}$ of storage, the presence of whey in packaging is an unacceptable trait for most American consumers. Overnight pressing did not prevent wheying off the first week of storage (2-4\% lost).

\section{Rheology and Texture}

Rheology. In small-amplitude oscillatory shear analyses, elastic modulus $\left(\mathrm{G}^{\prime}\right)$ is a measure of the energy stored and recovered per oscillation, and viscous modulus $\left(G^{\prime \prime}\right)$ is a measure of the energy dissipated and lost as heat per oscillation. The $\mathrm{G}^{\prime}$ and $\mathrm{G}^{\prime \prime}$ values for all salt treatments were initially between 26.6 and 32.4 $\mathrm{kPa}$, and $\mathrm{G}^{\prime \prime}$ values were from 7.19 to $8.6 \mathrm{kPa}$ (Figure 5). By 8 wk, $\mathrm{G}^{\prime}$ values had increased to 29.6 to $38.3 \mathrm{kPa}$ and $\mathrm{G}^{\prime \prime}$ values ranged from 7.44 to $9.14 \mathrm{kPa}$. Although values tended to increase with aging and $1.5 \%$ total salt $\mathrm{QF}$ were lower at wk 4 and 8 than other $\mathrm{QF}$, differences were not significant $(P>0.05)$. The $\mathrm{G}^{\prime}$ and $\mathrm{G}^{\prime \prime}$ values are relatively low for cheese, indicating that bonds between particles are being made and broken during each observation time, either spontaneously or from applied

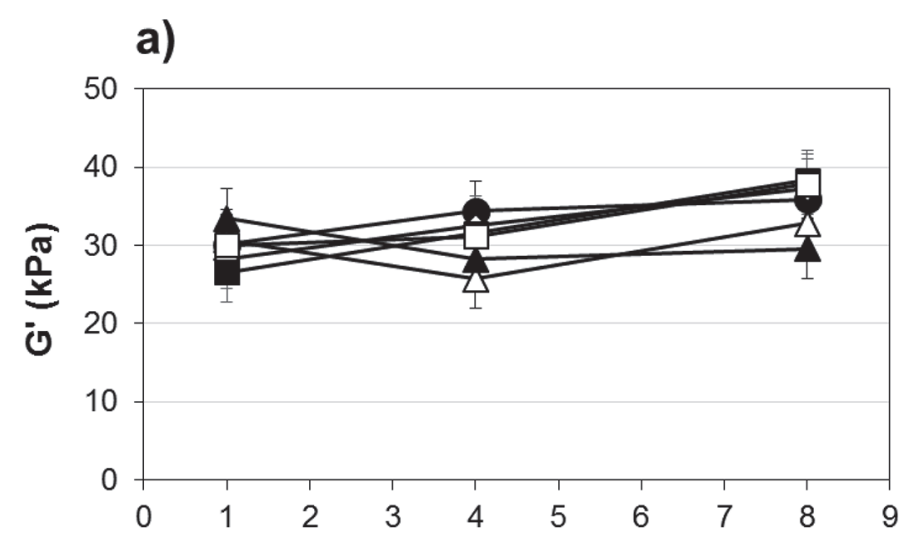

b)

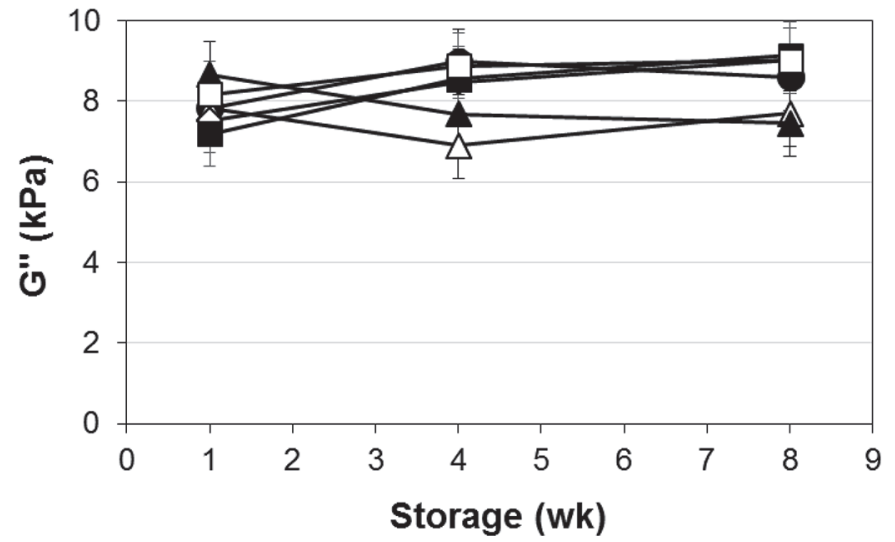

Figure 5. Means for viscoelastic properties [(a) elastic, $\mathrm{G}^{\prime}$ and (b) viscous, G" moduli] of Queso Fresco made with different salt blends over $12 \mathrm{wk}$ of $4^{\circ} \mathrm{C}$ storage; standard error bars are included. Salt blends $(\%, \mathrm{NaCl}-\mathrm{KCl}): 2.0-0, \mathbf{\bullet} ; 0.75-0.75, \Delta ; 1.0-0.5, \mathbf{\Delta} ; 1.0-1.0, \diamond ; 1.0-1.3$, $\mathbf{\square}$; and $1.0-1.5, \square$. 
a)

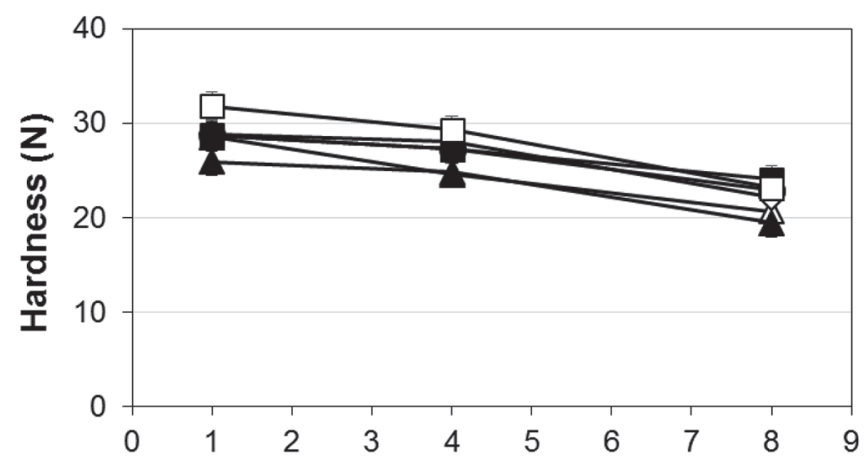

c)

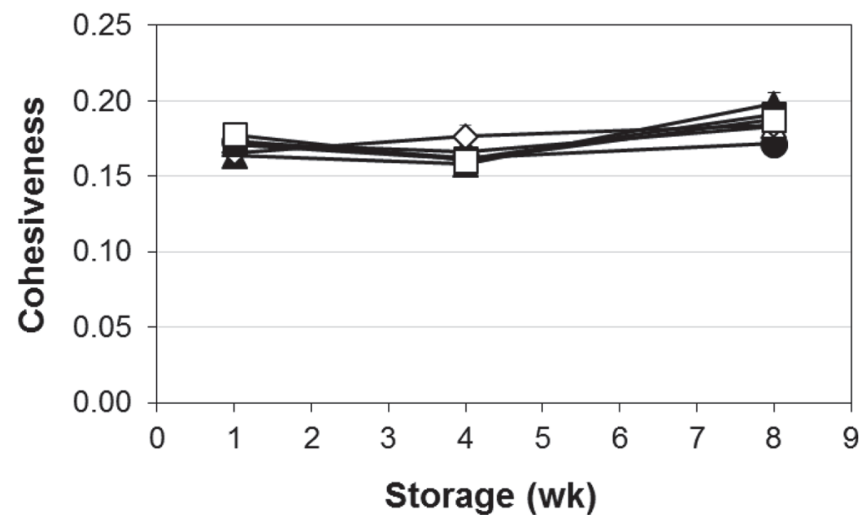

b)

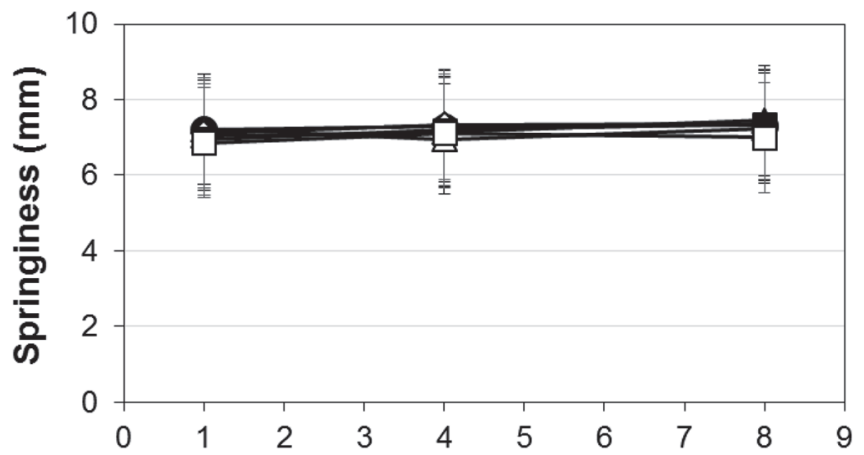

d)

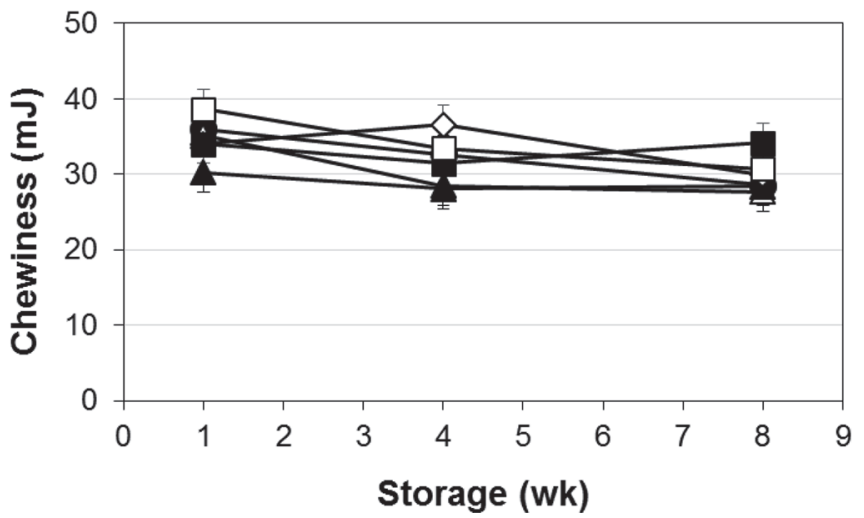

Figure 6. Means for textural properties [(a) hardness, (b) springiness, (c) cohesiveness, and (d) chewiness] of Queso Fresco made with different $\mathrm{Na}-\mathrm{K}$ salt blends over 12 wk of $4^{\circ} \mathrm{C}$ storage; standard error bars are included. Salt blends (\%, NaCl-KCl): 2.0-0, •; 0.75-0.75, $\Delta ; 1.0-0.5$, $\boldsymbol{\Delta} ; 1.0-1.0, \diamond ; 1.0-1.3, \mathbf{\square}$; and $1.0-1.5, \square$.

forces (Tunick, 2011). These results are expected for $\mathrm{QF}$, which has a granular and crumbly nature. Over time, loss of whey caused casein strands in the matrix to become drier and less mobile yet had minimal effect on viscoelastic properties.

Texture. In texture profile analysis, hardness is the amount of force required to compress a specimen, springiness is the height of recovery after the first compression (or "bite"), and cohesiveness is the ratio of the force-time areas from the 2 compressions (Tunick, 2000). At wk 1, 1.0-1.5 Na-K QF was harder than 1.0-0.5 Na-K QF (31.8 and 25.9 N, respectively; $P<0.05$ ), while no differences were noted among salt treatments for springiness, cohesiveness, and chewiness $(7.07 \pm 0.15 \mathrm{~mm}, 0.170 \pm 0.005$, and $34.7 \pm 02.75$, respectively) (Figure 6). Differences between salt treatments did not substantially change texture within the first 4 wk of storage. At wk 8, although no differences were noted among the salt treatments, hardness and chewiness had decreased to $22.0 \pm 1.73 \mathrm{~N}$ and $34.7 \pm$ $2.75 \mathrm{~mJ}$, respectively $(P<0.05)$, and cohesiveness had increased to $0.186 \pm 0.009(P<0.05)$. With storage, whey was forced out of the cheese with the first bite, which reduced force-time area, the force required to compress, and the recovery height. Hardness therefore decreased. Cohesiveness increased because force-time area of the second bite was relatively constant over time, and resulted in an increase in the ratio of the 2 force-time areas.

Sodium chloride, noted for enhancing protein hydration and solubility, especially $\kappa$-CN (f 1-105), contributes to forming tight and more continuous protein networks and affects curd formation (enhanced syneresis) and cheese rheology and texture (Guinee and Fox, 2004). Grummer et al. (2012) reported that $\mathrm{a}_{\mathrm{w}}$ of reduced-sodium cheese must be matched to full-salt cheese controls to minimize differences because of S/M. In that study, 2-mo-old Cheddar containing sea salt $\left(22 \% \mathrm{Na}, 9 \% \mathrm{~K}, 2 \% \mathrm{MgCl}_{2}\right.$, and $23 \%$ sulfate) were the hardest, while $2.5 \% \mathrm{NaCl}$ control and 1.2:1.7 Na:K were similar in hardness. The researchers concluded that the presence of the $\mathrm{MgCl}_{2}$ in the sea salt was responsible for the firmer matrix. Total replacement of sodium with other minerals resulted in softer Cheddar cheese, 
while partial replacement using salt blend affected protein and lipid breakdown without altering hardness (Fitzgerald and Buckley, 1985). In high moisture cottage cheese, reduction of $\mathrm{NaCl}$ by $50 \%$ did not alter consumer acceptability scores, but using $\mathrm{KCl}$ or $\mathrm{Na}-\mathrm{K}$ blends to reduce the sodium to $50 \%$ lowered the quality of the cheese (Lindsay et al., 1982). When $\mathrm{NaCl}$ content was reduced in QF without using a salt replacer, the only significant trend was higher shear stress and shear rigidity of $\mathrm{QF}$ as $\mathrm{NaCl}$ levels increased (Guo et al., 2011). The strength of the matrix (stress required to fracture) in $\mathrm{QF}$ containing $\leq 1.0 \% \mathrm{NaCl}$ decreased over time. Other than an increase at 8 wk in hardness as $\mathrm{KCl}$ concentration increased, the amount of $\mathrm{Na}-\mathrm{K}$ did not affect rheology or texture of QF.

Results from this study show that lowering $\mathrm{NaCl}$ to $1.0 \%$ and varying $\mathrm{KCl}$ levels from 0.5 to $1.5 \%$ in $\mathrm{QF}$ did not alter major components (moisture, fat, and protein) of the cheese, did not cause major variation in the formation or stability of the cheese matrix, and resulted in a weak-bodied cheese that crumbled easily. Within the curd, no excessive microbial growth, proteolysis, or lipolysis occurred, which contributed to maintaining the quality traits QF during $12 \mathrm{wk}$ of $4^{\circ} \mathrm{C}$ storage. Sensory evaluation targeted Na-K blends that matched $2.0 \% \mathrm{NaCl}$ control saltiness intensity, although future research is needed to confirm levels and to test consumer acceptance of reduced-sodium QF using Na-K blends. Further research is also needed to assess the food safety issues that arise when lowering $\mathrm{NaCl}$ content to $1.0 \%$ in $\mathrm{QF}$.

\section{CONCLUSIONS}

Reducing $\mathrm{NaCl}$ levels to $1 \%$ and adding 1 to $1.5 \%$ $\mathrm{KCl}$ had minimal effect on compositional, microbial, functional, and textural-rheological properties of QF, and adequate saltiness was obtained at 1.3 or $1.5 \%$ $\mathrm{KCl}$. Reducing $\mathrm{NaCl}$ level to $1 \%$ and adding 1.3 or $1.5 \%$ $\mathrm{KCl}$ during cheesemaking showed that $\mathrm{KCl}$ substitution was a viable route for reducing sodium in $\mathrm{QF}$, while retaining the desired quality traits and shelf life of the cheese. Results from this study will help in developing a reduced-sodium QF that meets the quality criteria of the cheese manufacturer and the health conscious consumer.

\section{ACKNOWLEDGMENTS}

Authors thank ARS scientists Raymond Kwoczak, Susan Iandola, Alberto Nuñez, Joe Uknalis, Brien Sullivan, and Julia Fischer for their contributions to this study. Mention of trade names or commercial products in this article is solely for the purpose of providing specific information and does not imply recommendation or endorsement by the U.S. Department of Agriculture.

\section{REFERENCES}

AOAC International. 2000. Official Methods of Analysis. 17th ed. AOAC Int., Gaithersburg, MD.

Ayyash, M. M., F. Sherkat, and N. P. Shah. 2012. The effect of $\mathrm{NaCl}$ substitution with $\mathrm{KCl}$ on Akawi cheese: Chemical composition, proteolysis, and angiotensin-converting enzyme-inhibitory activity, probiotic survival, texture profile, and sensory properties. J. Dairy Sci. 95:4747-4759.

Bastian, E. D., and R. J. Brown. 1996. Plasmin in milk and dairy products: An update. Int. Dairy J. 6:435-457.

Boziaris, I. S., P. N. Skandamis, M. Anastasiadi, and G.-J. E. Nychas. 2007. Effect of $\mathrm{NaCl}$ and $\mathrm{KCl}$ on fate and growth/no growth interfaces of Listeria monocytogenes Scott A at different $\mathrm{pH}$ and nisin concentrations. J. Appl. Microbiol. 102:796-805.

Christie, W. W. 2003. Lipid Analysis. 3rd ed. Oily Press, Bridgewater, UK.

Clark, S., H. Warner, and L. Luedecke. 2001. Acceptability of Queso Fresco cheese by traditional and nontraditional consumers. Food Sci. Technol. Int. 7:165-170. https://doi. org $/ 10.1177 / 108201320100700210$.

Cottrell, M. T., and D. L. Kirchman. 2000. Community composition of marine bacterioplankton determined by $16 \mathrm{~S}$ rRNA gene clone libraries and fluorescence in situ hybridization. Appl. Environ. Microbiol. 66:5116-5122. https://doi.org/10.1128/AEM.66.12.51165122.2000 .

Curioni, P. M. G., and J. O. Bosset. 2002. Key odorants in various cheese types as determined by gas chromatography-olfactometry. Int. Dairy J. 12:959-984. https://doi.org/10.1016/S09586946(02)00124-3.

Erba, D., S. Ciappellano, and G. Testolin. 2001. Effect of caseinphosphopeptides on inhibition of calcium intestinal absorption due to phosphate. Nutr. Res. 21:649-656. https://doi.org/10.1016/S02715317(01)00280-9.

Farrell, H. M. Jr., R. Jimenez-Flores, G. T. Bleck, E. M. Brown, J. E. Butler, L. K. Creamer, C. L. Hicks, C. M. Hollar, K. F. Ng-KwaiHang, and H. E. Swaisgood. 2004. Nomenclature of the proteins of cows' milk - Sixth revision. J. Dairy Sci. 87:1641-1674.

FDA. 2017. 21 CFR, Part 101.61. Nutrient content claims for the sodium content of foods. Accessed Feb. 1, 2017. https://www. accessdata.fda.gov/scripts/cdrh/cfdocs/cfcfr/CFRSearch. $\mathrm{cfm} ? \mathrm{fr}=101.61$.

Fitzgerald, E., and J. Buckley. 1985. Effect of total and partial substitution of sodium chloride on the quality of Cheddar cheese. J. Dairy Sci. 68:3127-3134. https://doi.org/10.3168/jds.S00220302(85)81217-0.

FitzGerald, R. J. 1998. Potential uses of caseinphosphopeptides. Int. Dairy J. 8:451-457.

Frank, D. C., C. M. Owen, and J. Patterson. 2004. Solid phase microextraction (SPME) combined with gas-chromatography and olfactometry-mass spectrometry for characterization of cheese aroma compounds. Lebensm. Wiss. Technol. 37:139-154. https:// doi.org/10.1016/ S0023-6438(03)00144-0.

Garde, S., M. Avila, E. Fernandez-Garcia, M. Medina, and M. Nuñez. 2007. Volatile compounds and aroma of Hispanico cheese manufactured using lacticin 481-producing Lactococcus lactis ssp. lactis INIA 639 as an adjunct culture. Int. Dairy J. 17:717-726. https:// doi.org/10.1016/j.idairyj.2006.07.005.

Grummer, J., M. Karalus, K. Zhang, Z. Vickers, and T. C. Schoenfuss. 2012. Manufacture of reduced-sodium Cheddar-style cheese with mineral salt replacers. J. Dairy Sci. 95:2830-2839.

Guinee, T. P., and P. F. Fox. 2004. Salt in cheese: Physical, chemical and biological aspects. Pages 207-259 in Cheese: Chemistry, Physics and Microbiology. Vol. 1, 3rd ed. P. F. Fox, P. L. H. McSwee- 
ney, T. M. Cogan, and T. P. Guinee, ed. Elsevier Academic Press, London, UK.

Guo, L., D. L. Van Hekken, P. M. Tomasula, J. Shieh, and M. H. Tunick. 2011. Effect of salt on the chemical, functional, and rheological properties of Queso Fresco during storage. Int. Dairy J. 21:352-357. https://doi.org/10.1016/j.idairyj.2010.12.009.

Guo, L., D. L. Van Hekken, P. M. Tomasula, M. H. Tunick, and G. Huo. 2012. Effect of salt on microbiology and proteolysis of Queso Fresco cheese during storage. Milchwissenschaft 67:74-77.

Hantsis-Zacharov, E., and M. Halpern. 2007. Culturable psychrotrophic bacterial communities in raw milk and their proteolytic and lipolytic traits. Appl. Environ. Microbiol. 73:7162-7168.

Johnson, M. E., R. Kapoor, D. J. McMahon, D. R. McCoy, and R. G. Narasimmon. 2009. Reduction of sodium and fat levels in natural and processed cheeses: Scientific and technological aspects. Compr. Rev. Food Sci. Food Saf. 8:252-268. https://doi.org/10.1111/ j.1541-4337.2009.00080.x.

Katsiari, M. C., E. Alichanidis, L. P. Voutsinas, and I. G. Roussis 2000. Proteolysis in reduced sodium Feta cheese made by partial substitution of $\mathrm{NaCl}$ by KCl. Int. Dairy J. 10:635-646. https://doi. org/10.1016/S0958-6946(00)00097-2.

Kosikowski, F. V., and V. V. Mistry. 1997. Latin American cheeses Pages 55-60 in Cheese and Fermented Foods. Vol. 2, 3rd ed. F. V. Kosikowski, ed. LLC, Westport, CT.

Leggett, L. N., P. M. Tomasula, D. L. Van Hekken, A. C. S. PortoFett, B. Shoyer, J. A. Renye, J. B. Luchansky, and N. Farkye. 2012. Effect of storage at 4 and 10C on the growth of Listeria monocytogenes in and on queso fresco. J. Food Saf. 32:236-245.

Le Quéré, J. L., and P. Molimard. 2002. Cheese: Cheese flavor. Pages 330-340 in Encyclopedia of Dairy Sciences. H. Roginski, J. W. Fuquay, and P. F. Fox, ed. Academic Press, San Diego, CA.

Lindsay, R. C., S. M. Hargett, and S. C. Bush. 1982. Effect of sodium/ potassium (1:1) chloride and low sodium chloride concentrations on quality of Cheddar cheese. J. Dairy Sci. 65:360-370. https:// doi.org/10.3168/jds.S0022-0302(82)82200-5.

McMahon, D. J. 2010. Issues with lower fat and lower salt cheeses. Aust. J. Dairy Technol. 65:200-205.

Meilgaard, M., G. V. Civille, and B. T. Carr. 1999. Spectrum intensity scales for descriptive analysis. Pages 197-205 in Sensory Evaluation Techniques. 3rd ed. CRC Press LLC, Boca Raton, FL.

Meisel, H., and R. J. FitzGerald. 2003. Biofunctional peptides from milk proteins: Mineral binding and cytomodulatory effects. Curr. Pharm. Des. 9:1289-1295.

Miquel, E., J. A. Gomez, A. Alegria, R. Barbera, R. Farre, and I. Recio. 2005. Identification of casein phosphopeptides released after simulated digestion of milk-based infant formulas. J. Agric. Food Chem. 53:3426-3433. https://doi.org/10.1021/jf0482111.

National Agricultural Statistical Service (NASS). 2016. Dairy Products 2015 Summary, April 2016, USDA. Accessed Dec. 1, 2016. http://usda.mannlib.cornell.edu/usda/current/DairProdSu/ DairProdSu-04-28-2016.pdf.

Ranieri, M. L., R. A. Ivy, W. R. Mitchell, E. Call, S. N. Masiello, M. Wiedmann, and K. J. Boor. 2012. Real-time PCR detection of
Paenibacillus spp. in raw milk to predict shelf life performance of pasteurized fluid milk products. Appl. Environ. Microbiol. 78:5855-5863.

Schroeder, C. L., F. W. Bodyfelt, C. J. Wyatt, and M. R. McDaniel. 1988. Reduction of sodium chloride in Cheddar cheese: Effect on sensory, microbiological, and chemical properties. J. Dairy Sci 71:2010-2020. https://doi.org/10.3168/jds.S0022-0302(88)797763.

Torres, N., and R. C. Chandan. 1981. Flavor and texture development in Latin American white cheese. J. Dairy Sci. 64:2161-2169.

Tunick, M. H. 2000. Rheology of dairy foods that gel, stretch, and fracture. J. Dairy Sci. 83:1892-1898. https://doi.org/10.3168/jds. S0022-0302(00)75062-4.

Tunick, M. H. 2011. Small strain dynamic rheology of food protein networks. J. Agric. Food Chem. 59:1481-1486. https://doi. org $/ 10.1021 /$ jf1016237.

Tunick, M. H., D. X. Ren, D. L. Van Hekken, L. Bonnaillie, M. Paul, R. Kwoczak, and P. M. Tomasula. 2016. Effect of heat and homogenization on in vitro digestion of milk. J. Dairy Sci. 99:4124-4139. https://doi.org/10.3168/jds.2015-10474.

Tunick, M. H., D. L. Van Hekken, S. K. Iandola, and P. M. Tomasula. 2012. Characterization of Queso Fresco during storage at 4 and $10^{\circ} \mathrm{C}$. J. Food Res. 1:308-319. https://doi.org/10.5539/jfr. v1n1p308.

Upadhyay, V. K., P. L. H. McSweeney, A. A. A. Magboul, and P. F. Fox. 2004. Proteolysis in cheese during ripening. Pages 391-433 in Cheese: Chemistry, Physics and Microbiology. Vol. 1, 3rd ed. P. F. Fox, P. L. H. McSweeney, T. M. Cogan, and T. P. Guinee, ed. Elsevier Academic Press, London, UK.

USDA.2010. Sodium, potassium, and water.AccessedDec.8,2014.http:// www.cnpp.usda.gov/Publications/DietaryGuidelines/2010/ DGAC/Report/D-6-SodiumPotassiumWater.pdf.

USDA. 2016 National Nutrient Database for Standard Reference (Release 28, revised May 2016). Accessed Feb. 1, 2017. https://ndb. nal.usda.gov/ndb/.

Van Hekken, D. L., and N. Y. Farkye. 2003. Hispanic cheeses: The quest for queso. Food Technol. 57:32-38.

Van Hekken, D. L., Y. W. Park, and M. H. Tunick. 2013a. Effects of reducing fat content on the proteolytic and rheological properties of Cheddar-like caprine milk cheese. Small Rumin. Res. 110:46-51. https://doi.org/10.1016/j.smallrumres.2012.11.034.

Van Hekken, D. L., M. H. Tunick, N. Y. Farkye, and P. M. Tomasula. 2013b. Effect of hydrostatic high-pressure processing on the chemical, functional, and rheological properties of starter-free Queso Fresco. J. Dairy Sci. 96:6147-6160. https://doi.org/10.3168/ jds.2012-6212

Van Hekken, D. L., M. H. Tunick, L. N. Leggett, and P. M. Tomasula. 2012. Impact of curd milling on the chemical, functional, and rheological properties of starter-free Queso Fresco. J. Dairy Sci. 95:5527-5535. https://doi.org/10.3168/jds.2011-4933. 